\title{
Anomalous hypertrophied muscle band in LV mimicking LV mass
}

Shivakumar Bhairappa, Himanshu Mahla, Sunil Kumar KR, Cholenahally Nanjappa Manjunath

\section{DESCRIPTION}

Department of Cardiology, Sri Jayadeva Institute of Cardiovasular Sciences and Research, Bengaluru, Karnataka, India

\section{Correspondence to} Dr Shivakumar Bhairappa, snbhairappa@gmail.com

\section{CrossMark}

\section{To cite: Bhairappa $S$,}

Mahla H, KR SK, et al. BMJ Case Rep Published online: [please include Day Month Year] doi:10.1136/bcr-2013200819
A 37-year-old man referred for non-cardiac chest pain evaluation to our tertiary care centre. There

were no risk factors for coronary artery disease. Clinical examination and 12-lead ECG were normal. Transthoracic echocardiogram revealed a

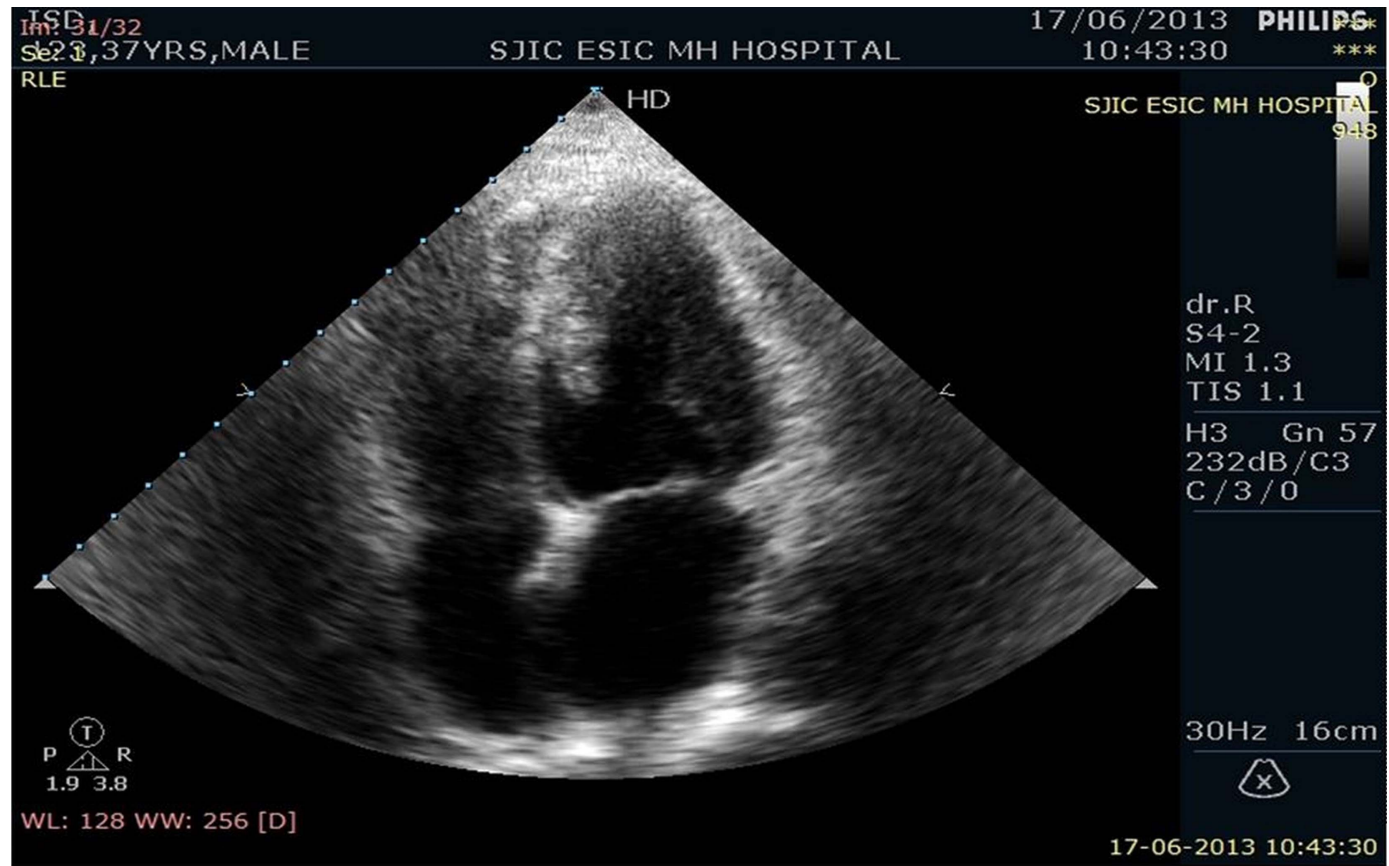

Figure 1 Apical 4-chamber view in transthoracic echocardiogram showing finger-like projection in paraseptal region.

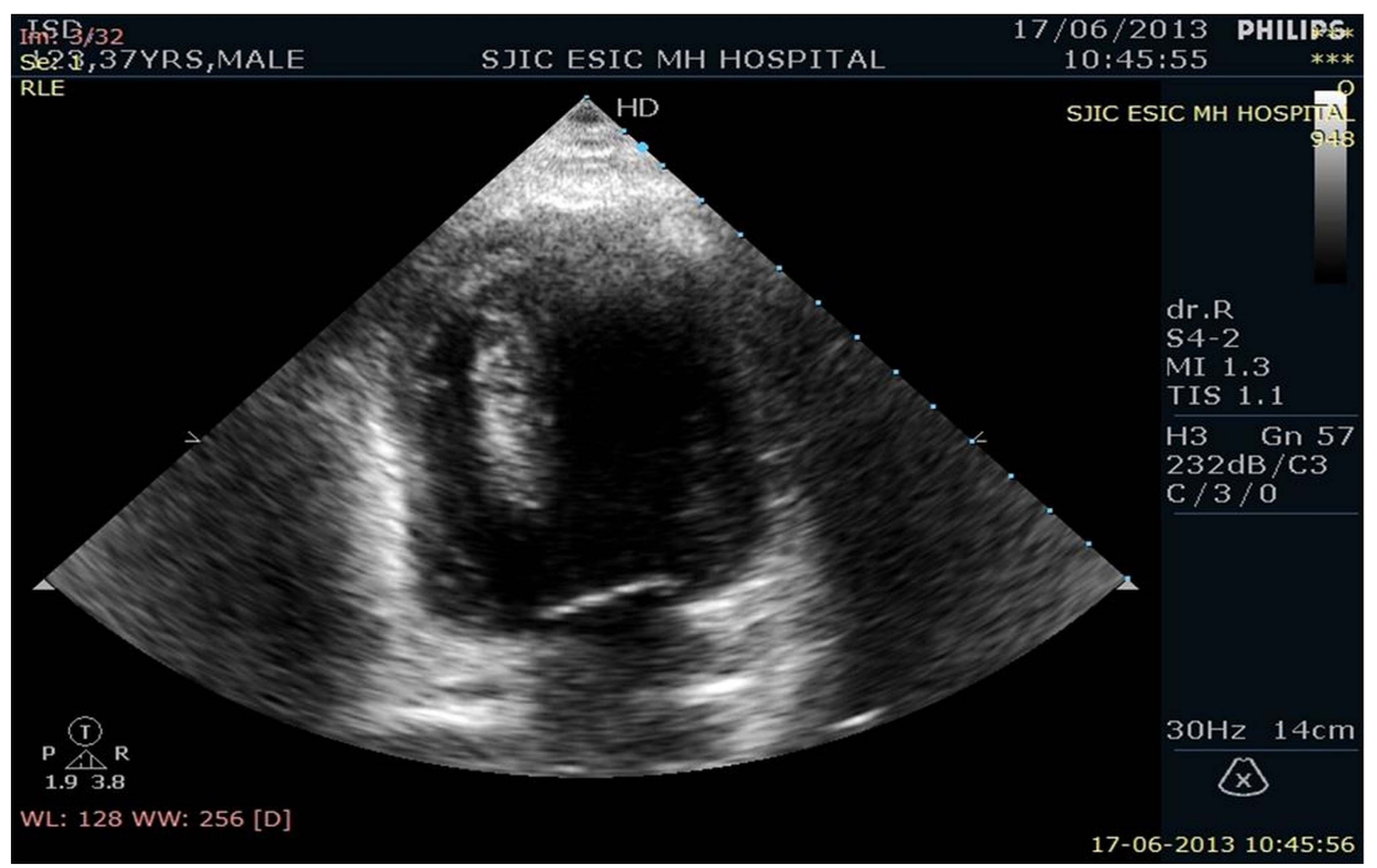

Figure 2 Apical 2-chamber view in transthoracic echocardiogram showing finger-like projection in paraseptal region and attached to apex. 


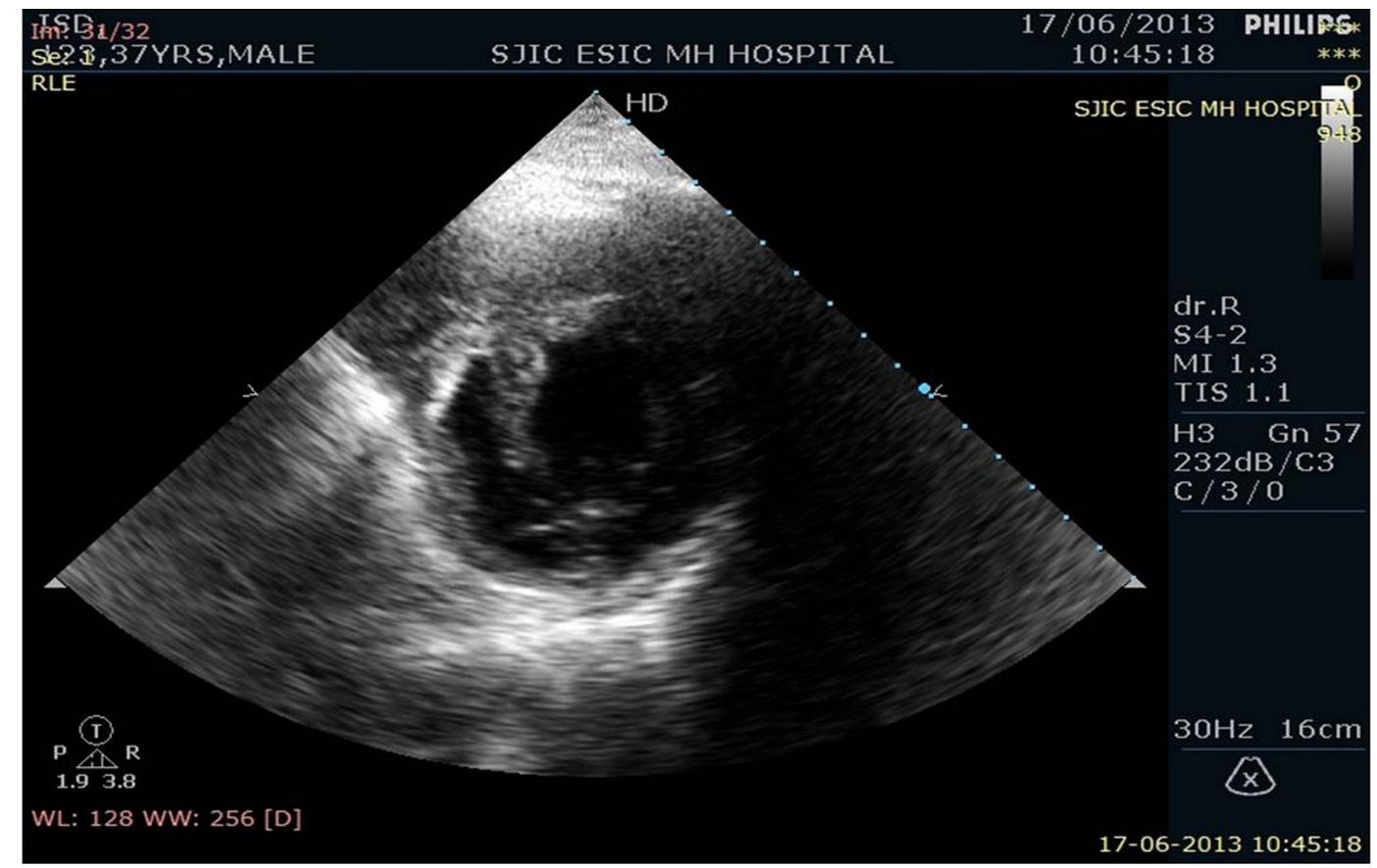

Figure 3 Parasternal short axis view in transthoracic echocardiogram showing finger-like projection in paraseptal region.

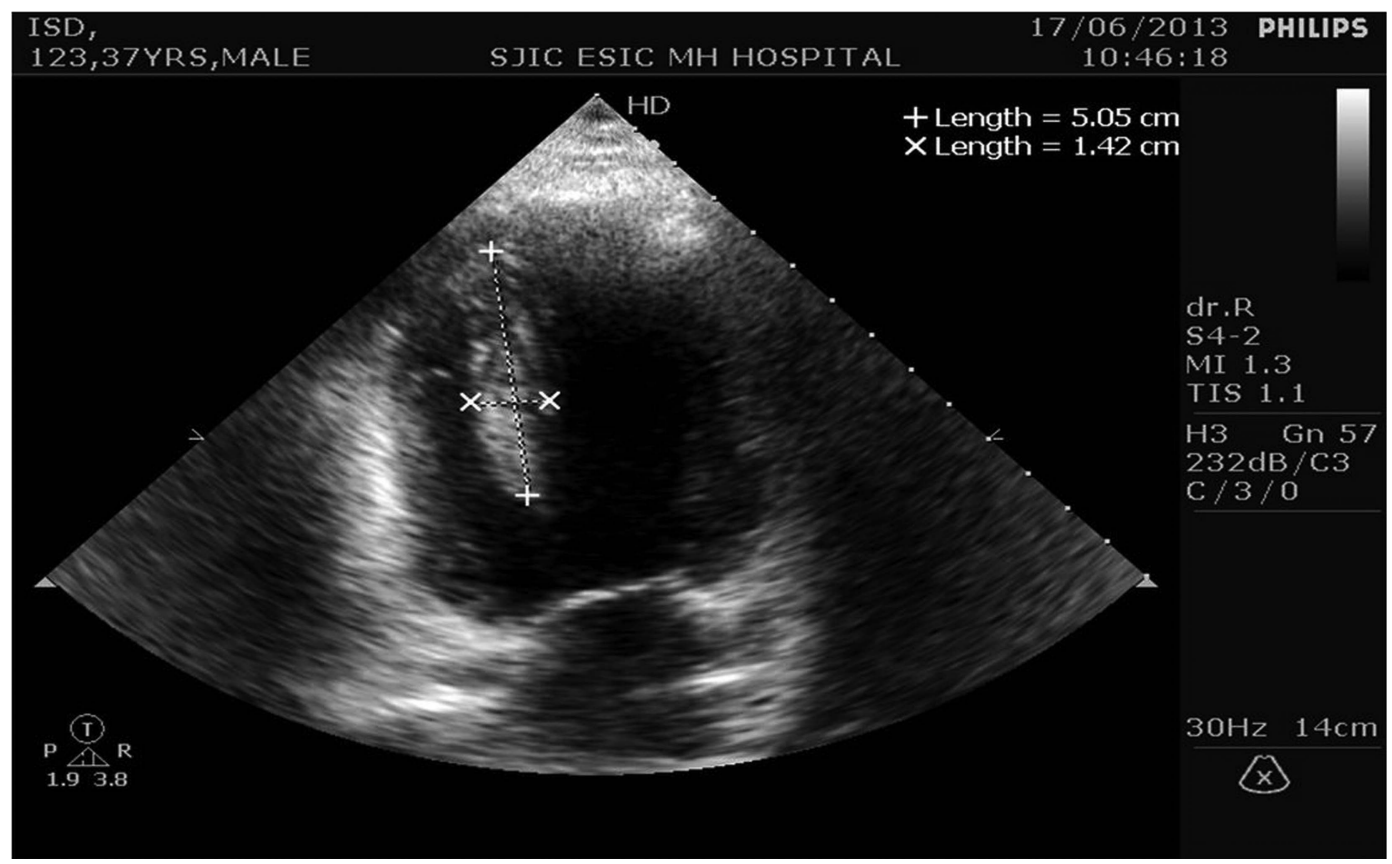

Figure 4 Apical 2-chamber view in transthoracic echocardiogram showing the band in paraseptal region with dimensions.

finger-like projection in the paraseptal region towards the left ventricle (LV) measuring $5 \times 1.4 \mathrm{~cm}$ (figures $1-4$; videos $1-4$ ). Grossly, it was mimicking LV mass without any gradient across (as opposed to hypertrophic cardiomyopathy). There was no evidence of left ventricular hypertrophy (neither concentric nor eccentric). Echotexture was the same as that of septum. MRI was performed to characterise the finger-like projection (figures 5 and 6; video 5). It proved to be a hypertrophied muscle band in LV as no different MR signals (hyperintense or hypointense) were found on cardiac MRI. Patient is on follow-up with crucial vigilance regarding any rhythm disturbance without any medications currently. A hypertrophied muscle band in LV can sometimes mimic apical cardiomyopathy ${ }^{1}$ or LV mass. It is a rare echocardiographic finding in patients with normal LV wall thickness. Sometimes these bands may be associated with rhythm ${ }^{2}$ disturbances but most of the cases have benign course. We confirmed our finding by cardiac MRI which is better for tissue characterisation. 


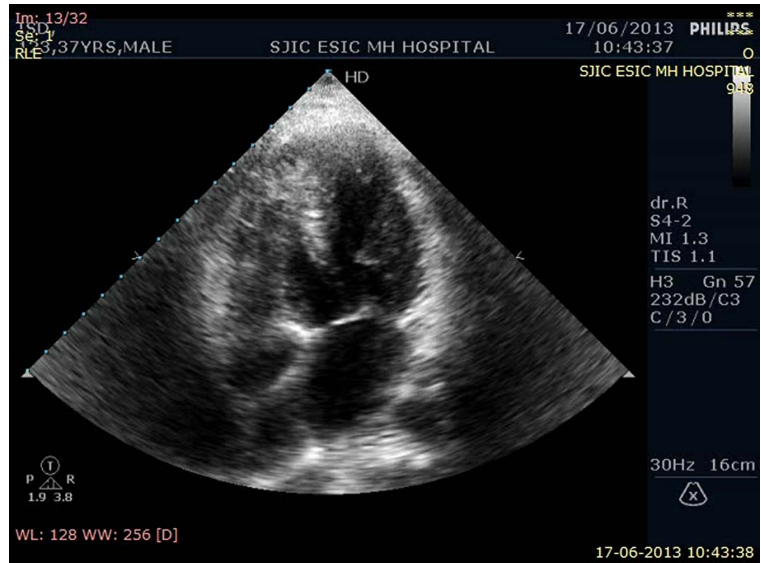

Video 1 Apical 4 chamber view in TTE showing finger like projection in paraseptal region.

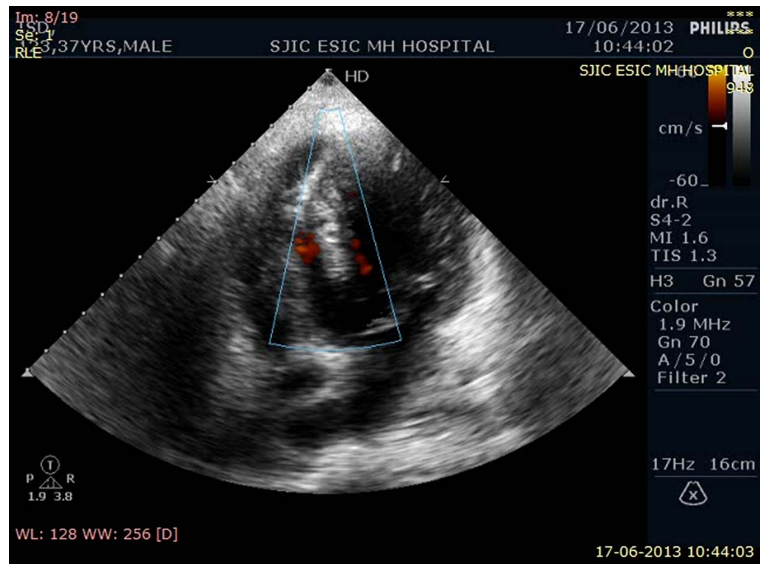

Video 2 Apical 4 chamber view in TTE with colour Doppler with no evidence of any turbulence around the finger like structure.

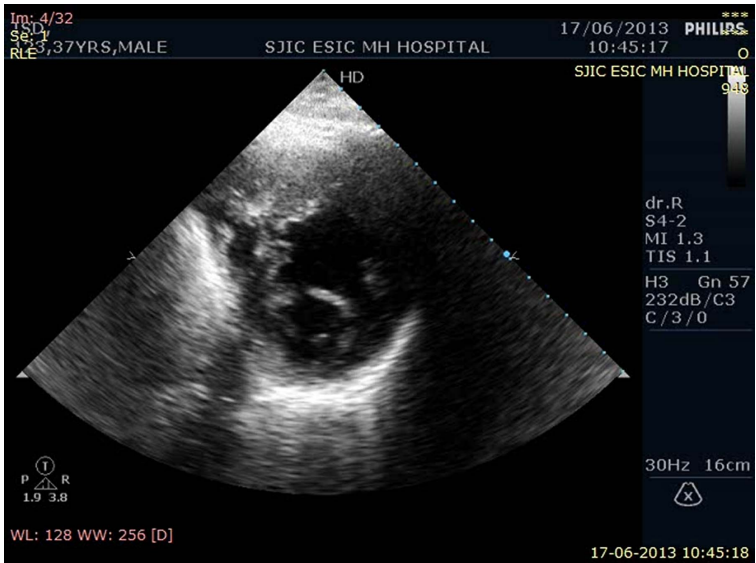

Video 3 Parasternal short axis view in TTE showing finger like projection in paraseptal region.

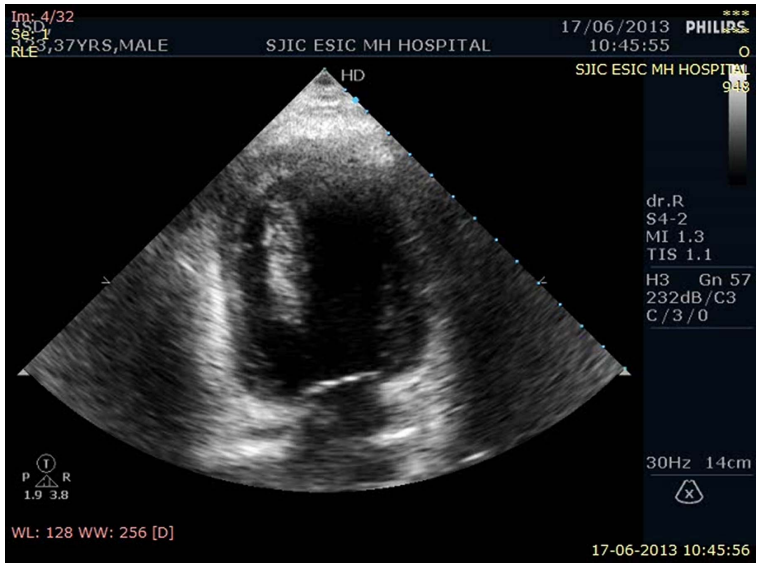

Video 4 Modified apical 3 chamber view showing like projection in paraseptal region with attachment to apex.

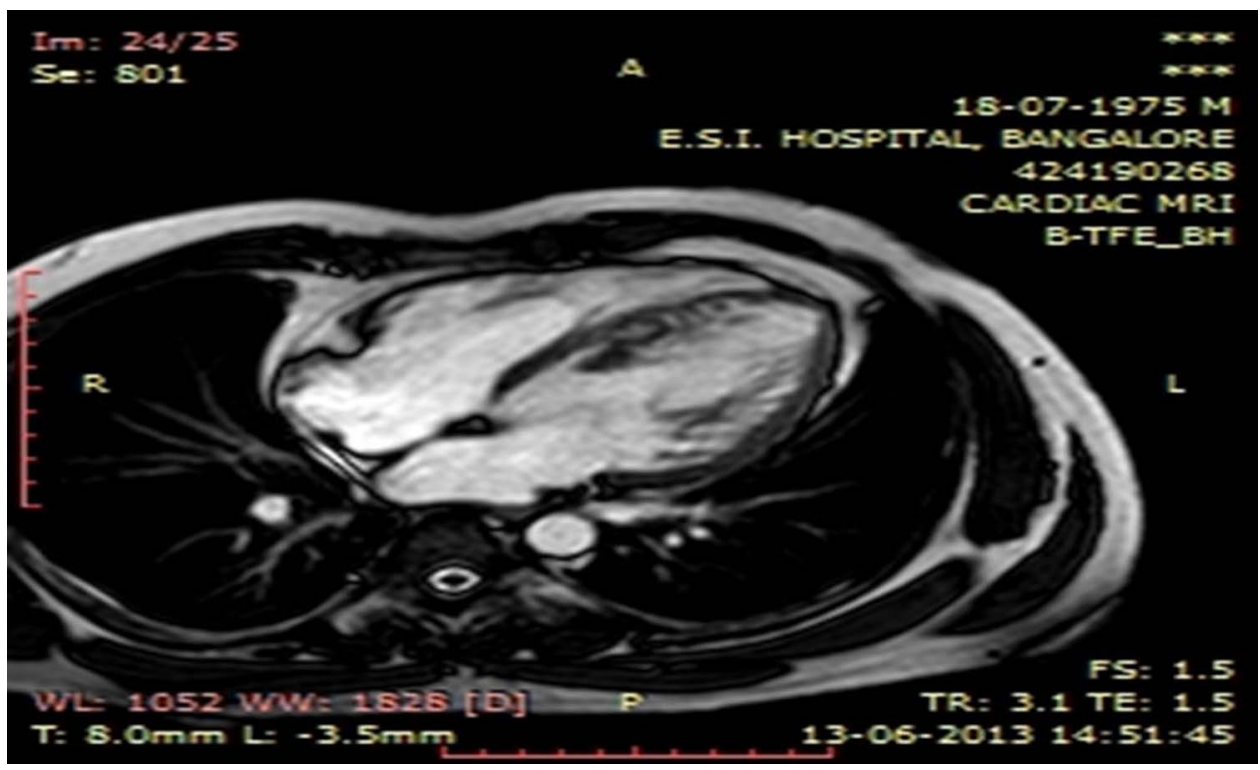

Figure 5 Cardiac MRI showing the 4-chamber view at mid-systole with no extraordinary tissue brightness. 


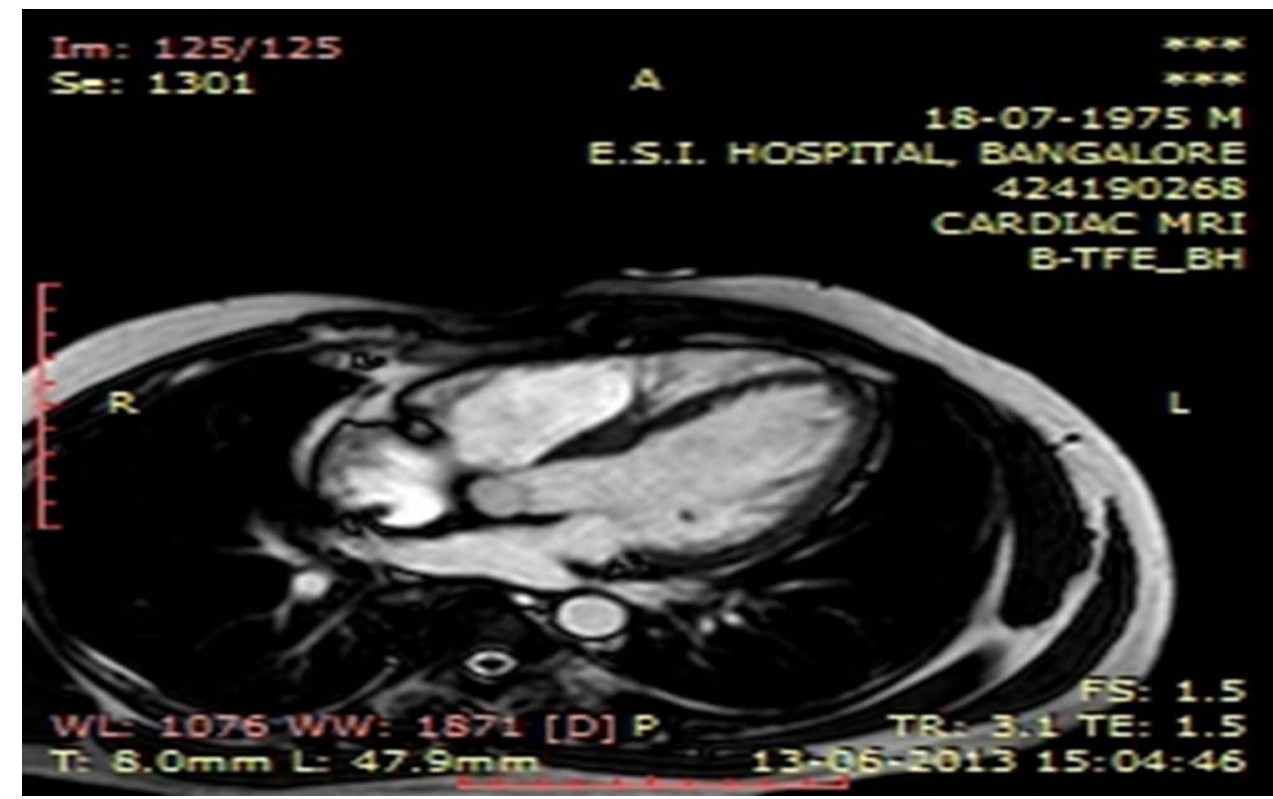

Figure 6 Cardiac MRI showing the 4-chamber view at mid-diastole with no extraordinary tissue brightness.

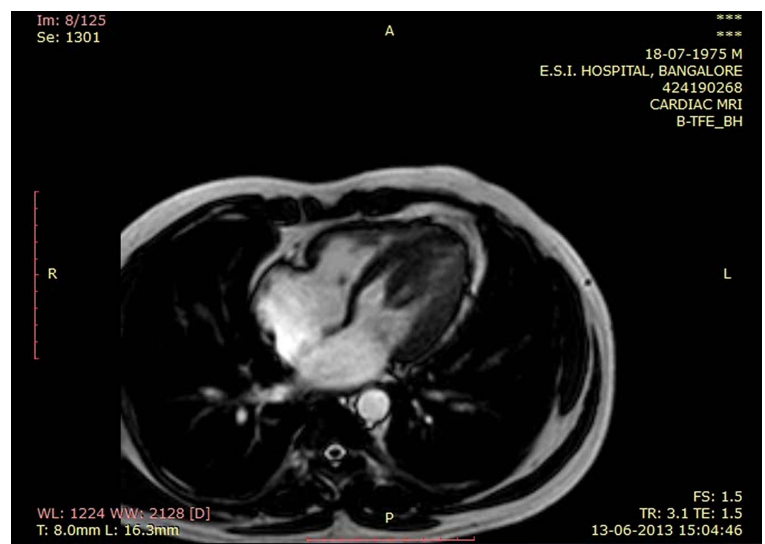

Video 5 Cardiac MRI showing the 4 chamber view in one cardiac cycle with no extraordinary tissue brightness.

\section{Learning points}

Hypertrophied muscle band in the left ventricle (LV) can mimic LV mass.

- The best way to differentiate it from mass is MRI which is better for tissue characterisation.

- Although in most cases it is benign, sometimes it can cause rhythm disturbances or can produce gradients in the left ventricular outflow tract like hypertrophic cardiomyopathy.
Acknowledgements The authors are thankful to Mrs Mythri K Gowda for his kind support and cooperation.

Contributors All authors were involved in the writing of this article and with patient care.

Competing interests None.

Patient consent Obtained.

Provenance and peer review Not commissioned; externally peer reviewed.

\section{REFERENCES}

1 Lee $\mathrm{SH}$, Ryu HM, et al. A case of an anomalous hypertrophied muscle band in the left ventricle. J Cardiovasc Ultrasound 2012;20:97-9.

2 Salazar J. Left ventricular anomalous muscle band and electrocardiographic repolarization changes. Pediatr Cardiol 1997;18:434-6. 
Copyright 2013 BMJ Publishing Group. All rights reserved. For permission to reuse any of this content visit http://group.bmj.com/group/rights-licensing/permissions.

BMJ Case Report Fellows may re-use this article for personal use and teaching without any further permission.

Become a Fellow of BMJ Case Reports today and you can:

- Submit as many cases as you like

- Enjoy fast sympathetic peer review and rapid publication of accepted articles

- Access all the published articles

- Re-use any of the published material for personal use and teaching without further permission

For information on Institutional Fellowships contact consortiasales@bmjgroup.com

Visit casereports.bmj.com for more articles like this and to become a Fellow 